\title{
МЕДСЕСТРИНСЬКИЙ ПРОЦЕС У ПЕРІОД РЕАБІЛІТАЦІЇ ПІСЛЯ ПЕРЕНЕСЕНОГО ІНСУЛЬТУ В ДОМАШНІХ УМОВАХ
}

\author{
I. I. Луньова
}

Вищий навчальний заклад «Київський міський медичний коледж»

У статті розглянуто роль медичної сестри і родичів пацієнта у наданні допомоги хворим, які перенесли інсульт. Розглянуто основні моменти, на які необхідно звертати увагу медичним сестрам та родичам пацієнтів при наданні допомоги в період реабілітації після перенесеного інсульту.

\section{NURSING PROCESS AT DOMICILIARY CARE DURING THE REHABILITATION PERIOD AFTER CEREBROVASCULAR ACCIDENT}

\section{I. Luniova}

\section{Kyiv Municipal Medical College}

\begin{abstract}
This article considers the nurse's role for family members' education during the care of patients who had cardiovascular accident. We considered the main points deserving attention from nurses and patient's relatives when they take care of them during the rehabilitation after stroke history.
\end{abstract}

Вступ. Україна посідає одне з перших місць у європі за показниками захворюваності на гострі порушення мозкового кровообігу (ГПМК) та смертності від інсульту. За даними офіційної статистики МОЗ України, щорічно понад 110 тис. українців хворіють на інсульт. Лише у Києві фіксується 6 тис. нових випадків інсульту на рік. Понад третину з тих, хто захворів, складають люди працездатного віку. 30-40 \% хворих на інсульт помирають впродовж перших 30 днів і до 50 \% - протягом 1 року від початку захворювання; 20-40 \% хворих, які вижили, стають залежними від сторонньої допомоги (12,5 \% первинної інвалідності) і тільки близько $10 \%$ повертаються до повноцінного життя [5].

У більшості випадків наслідком ГПМК $є$ не смерть, а обмеження життєдіяльності, тому інсульти є провідною причиною інвалідності серед людей старшої вікової групи. В Україні проводиться велика робота 3 вдосконалення надання сучасної допомоги хворим на ГПМК. Зокрема, у 2012 р. вийшов у світ Уніфікований клінічний протокол медичної допомоги «Ішемічний інсульт», підготовлений фахівцями МОЗ України [3].

Мета сестринського догляду визначається так: «створити для пацієнта сприятливі умови для активізації його особистих сил». Медична сестра повинна володіти професійною спостережливістю, () І. І. Луньова, 2016 що дозволяє побачити, запам'ятати і професійно оцінити найменші зміни у фізичному, психологічному стані пацієнта, вміти володіти собою, навчитися керувати своїми емоціями. Працюючи на різних етапах медсестринського процесу і маючи глибоке теоретичне підґрунтя 3 «Основ медсестринства», «Неврології», «Реабілітації» та «Сімейної медицини», медсестра може стати справжнім членом лікувальної бригади, яка здійснює догляд за пацієнтом і вміє навчити родичів та друзів пацієнта особливостям цього догляду [1].

Основна частина. Інсульт (інфаркт головного мозку) - захворювання серцево-судинної системи, при якому порушується кровопостачання мозку. Під інсультом розуміють гостре порушення мозкового кровообігу, яке розвивається в результаті тромбозу або звуження мозкових судин.

Цей патологічний стан відомий ще з часів Гіппократа, який називав його апоплексією. І лише на початку XX століття інсульт був офіційно розділений на два підтипи: геморагічний та ішемічний. У разі ішемічного типу відбувається зниження або повне припинення кровотоку церебральними артеріями. При геморагічному типі розвивається крововилив у речовину головного мозку, субарахноїдальний простір або шлуночки [2]. 
Обсяг ураження мозкової тканини залежить від масивності крововиливу (чим швидше буде зупинено кровотечу, тим сприятливіший прогноз).

Ішемічний інсульт головного мозку, або інфаркт, супроводжується некрозом і загибеллю нейронів із порушенням функції тієї частини центральної нервової системи, в якій він розвинувся. Як правило, інфаркти мозку при невеликих розмірах і локалізації у півкулі мають достатньо сприятливий прогноз, а відновлювальний період може перебігати швидко і досить ефективно.

Інсульт на сьогодні залишається однією з найгостріших медико-соціальних проблем та завдає величезного економічного збитку суспільству: він займає третє, а за даними деяких дослідників - друге місце серед причин смертності дорослого населення і $\epsilon$ головною причиною тривалої інвалідності.

Поверненню в соціальне середовище тих, хто перехворів на інсульт, сприяє відновлювальна терапія, подальша психологічна підтримка та амбулаторний нагляд з продовженням реабілітаційних практик та профілактики розвитку повторного інсульту. Але комплексність і адекватність ранніх реабілітаційних заходів необхідно забезпечити не тільки в умовах стаціонару, а й продовжити і в умовах поліклініки, і вдома. Адже залишаються питання профілактики розвитку повторного інсульту, продовження реабілітаційних практик, виникає необхідність подальшої психологічної підтримки та амбулаторного нагляду [7].

Відновлювальна терапія повинна відбуватися постійно, а позитивні результати досягаються тільки завдяки правильно організованому догляду та реабілітації, оскільки тільки фахова реабілітація допомагає прискорити темп і зробити повнішими відновлення порушених функцій та запобігти розвитку вторинних ускладнень [2].

\section{Як допомогти близькій людині в реабілітації?}

Реабілітацією прийнято вважати навчання відновленню втрачених функцій. Існує ряд спеціальних вправ для хворих, що перенесли інсульт, які або допомагають відновити втрачені можливості, або адаптуватися до нових умов життя.

Основними причинами, внаслідок яких хворі не можуть обслуговувати себе, є порушення рухів, свідомості, розлади функцій тазових органів, порушення мови та інших функцій кори головного мозку.

Відновні заходи повинні підбиратися і проводитися індивідуально залежно від тяжкості стану і характеру порушень, проте всім хворим вони проводяться за такими основними напрямками:
1. Використання лікувальної фізкультури та масажу для корекції рухових розладів.

2. Відновлення мови і пам'яті.

3. Психологічна та соціальна реабілітація хворого в сім'ї та суспільстві.

4. Профілактика відтермінованих постінсультних ускладнень і повторного інсульту з урахуванням наявних факторів ризику.

Реабілітація, що починається в лікарні, в домашніх умовах набуває ще важливішого значення. Поліпшення стану хворого після інсульту відбувається дуже повільно і вимагає від людини, яка доглядає за хворим, значного терпіння.

Чим більше вдасться зберегти нервових клітин навколо вогнища ушкодження в ранньому постінсультному періоді, тим ефективніші будуть і подальше лікування і період відновлення.

Медична сестра, знаючи всі правила і методи реабілітації, може навчити родичів самостійно виконувати всі процедури вдома. Але спочатку вона має бути присутня при проведенні всіх етапів реабілітації і корегувати їх виконання. Тільки після того, як медсестра переконається в правильному виконанні всіх процедур, вона може повністю покластися на родичів або близьких людей, які будуть їх проводити [1].

Період реабілітації після перенесеного інсульту досить складний для пацієнта. При ненаданні йому відповідної допомоги, виникає високий ризик незворотного порушення всіх функцій організму хворого. Найважливіше в даному періоді - дотримання певних правил, принципів і норм у спілкуванні з пацієнтом.

Завжди необхідно пам'ятати, що лікування інсульту - процес не одноденний і не тижневий - тільки завзяте і правильне лікування буде ефективним і приведе до належного одужання.

Насамперед потрібно виробити розпорядок дня, що поліпшить готовність хворого до тих чи інших занять і процедур. Вправи повинні бути короткими, але регулярними. Краще, якщо вони повторюються декілька разів протягом дня.

Хворому необхідна Ваша підтримка і похвала навіть за мінімальні досягнення!

\section{лікарська терапія}

Медикаментозне лікування після інсульту призначається вже в реанімації. Точність і правильність введення певних доз медикаментів дозволяє вивести пацієнта з коми і обмежити ділянку ураження при геморагічному інсульті, а при ішемічному інсульті відновити мозковий кровообіг. Після переведення 
пацієнта у відділення, йому призначається підтримувальна терапія, що дозволяє закріпити досягнуті результати. Потрібно ретельно простежити за тим, щоб пацієнт справно приймав всі призначені йому ліки. Якщо ж він не може приймати їх самостійно, потрібно допомогти йому в цьому (іноді підтримати голову, допомогти проковтнути, подрібнити таблетку до порошкоподібного стану) [13].

Догляд за хворими з паралічами потребує особливо ретельного стеження за чистотою шкіри і регулярністю випорожнення сечового міхура. Комплекс заходів із догляду за ними включає дотримання правил гігієни (умивання, догляд за ротовою порожниною), зміну білизни, профілактику пролежнів і гіпостатичної пневмонії.

Своєчасне і раннє застосування адекватного фізичного навантаження в комплексному лікуванні наслідків ГПМК дуже часто має вирішальне значення у подальшому відновленні таких пацієнтів. Адже фізичні вправи і рання мобілізація $\epsilon$ ефективною профілактикою контрактур, пролежнів, тромбоемболій, утворення патологічних поз, застійних явищ у легенях, розвитку спастичності м'язів, що $\epsilon$ характерним для осіб, які перенесли мозковий інсульт. Рання і адекватна рухова активність допомагає відновити втрачені функції, зменшує руховий дефект і покращує загальний фізичний та психоемоційний стан хворого [4].

Для запобігання контрактурам паралізовані кінцівки потрібно правильно укладати, використовувати спеціальні лонгети, здійснювати лікувальну гімнастику і масаж.

Лікування після інсульту в домашніх умовах починається відразу після виписування з лікарні. Допомога потерпілому повинна бути така ж, як і в стаціонарі (підтримати пацієнта, нахилити його, подати води). Ні в якому разі не можна допустити, щоб хворий пропустив приймання ліків.

\section{лікувальна фізкультура}

Для відновлення м'язової активності відразу ж після того, як пройшов гострий період і пацієнт уже почав самостійно вставати і сідати, потрібно проводити спеціальні вправи після інсульту.

Лікувальна фізкультура включає гімнастику (згинання та розгинання рук і ніг, розминку пальців, спроби плетіння або складання дрібних пазлів) і масаж.

Особливо дієвим є відновлювальний масаж. Його рекомендується проводити щоденно, починаючи з периферії кінцівки і піднімаючись до тулуба. Він дозволяє відновити кровообіг в ураженій кінцівці, м'язовий тонус.

Найкраще разом з хворим проводити вправи в басейні. Вода допомагає знизити навантаження, що припадає на уражені кінцівки, в результаті чого рухова реабілітація після інсульту настає набагато швидше.

Після виконання вправ рекомендуються розслаблювальні ванни і гіпнотерапія.

\section{З чого починати вправи лежачому хворому після інсульту?}

Emanu реабілітації:

1 етап

3 перших годин гострого періоду інсульту застосовується лікування положенням, щоб уникнути контрактур паралізованих кінцівок. Також роблять пасивну гімнастику.

\section{2 етап}

До кінця першого тижня призначають активну гімнастику, розроблену інструкторами ЛФК у стаціонарі. Ї̈̈ спочатку виконують в ізометричному режимі, без руху в суглобах. Хворі кінцівки піднімає помічник, а мета хворого утримувати підняту руку чи ногу. Руку не можна піднімати за кисть. якщо хвору руку піднімає сам хворий, здоровою рукою він повинен піднімати їі за лікоть, кисть повертати долонею вгору, якщо руку піднімає помічник, то однією рукою береться вище ліктя знизу, а іншою рукою за зап'ястя зверху.

З етап

Хворого навчають сидіти. Починають з 3-5 хвилин напівлежачи, поклавши під спину і голову подушки, через 2-3 дня переводять лежачого хворого в напіввертикальне положення.

Потім садять на ліжку з опущеними вниз ногами, підставивши під них лавку.

\section{4 етап}

Зміцнення м'язів ніг. Вправи проводять за допомогою еспандера або насоса-жаби для надування гумових матраців. У лежачому положенні роблять вправу «імітація ходьби» - ноги згинають і розгинають у колінах, ступні ніг ковзають по простирадлі.

\section{$\underline{5 \text { етап }}$}

Ходьба. Хворий з сидячого положення намагається підвестися, тримаючись за стійку опору - спинку ліжка, поруч стоїть стілець або крісло. Коли хворий навчиться впевнено стояти, він повинен почати переступати 3 ноги на ногу. Освоївши цю вправу, можна переходити до ходьби на місці, тримаючись за спинку ліжка. Потім намагаються ходити на місці без опори $[8,11]$. 
I надалі, головне в реабілітації після інсульту - че ходьба. Обирайте рівні маршрути без підйомів, з лавками для відпочинку. Поступово збільшуйте дистанцію. Темп ходьби повільний - 40-50 кроків за хвилину, відпочинок через кожні 5-10 хвилин.

Не жалійте паралізовану сторону: непрацюючі м'язи неможливо відновити!

У хворих після інсульту часто виникають труднощі з жуванням і ковтанням їжі.

Варто пам'ятати, що через захворювання більшість пацієнтів втрачає здатність до самостійного харчування. Потрібно активно допомагати їм при споживанні їжі (на початкових етапах підтримувати тарілку і ложку, попереджати перхання пацієнтів). Згодом, коли хворий вже сам намагатиметься себе обслуговувати, необхідно стежити за тим, як пацієнт їсть, а при необхідності - допомагати йому.

Хворі після інсульту потребують правильного здорового харчування. Раціон потрібно наповнити овочами та фруктами, м'ясом. Тільки так забезпечується найбільш ефективне відновлення уражених ділянок головного мозку. 3 повсякденного вжитку необхідно вилучити всі продукти, що підвищують артеріальний тиск, а також гостре, копчене. Не потрібно годувати пацієнтів сипучими продуктами, оскільки високий ризик їх потрапляння в дихальні шляхи [10].

Особливо обережно треба годувати хворих із порушеннями ковтання, оскільки потрапляння їжі в трахею і бронхи може спричинити аспіраційну пневмонію. Якщо довільне ковтання не можливе, хворих годують через зонд.

\section{На що необхідно звернути увагу?}

- Їжа для хворого повинна бути комфортної температури, повинна добре пережовуватися і проковтуватися.

- Важливим є приємний запах їжі, який, як відомо, стимулює вироблення слини, що також може допомогти.

- Не давайте хворому їжу підвищеної в'язкості (сиропи, банани).

- Краще утриматися від рису, який може прилипати до стінок ротової порожнини, краще додавати його у перші страви.

- Виділяйте хворому більше часу на споживання їжі (до 40 хв), після їжі потрібно затриматися в сидячому положенні на 45-60 хв.

- Переконайтеся, що в роті не затримуються шматочки їжі після проковтування.

- Столові прибори для хворого повинні бути 3 широкою ручкою, щоб було зручніше їх утримувати.
При багатьох захворюваннях нервової системи виникають порушення функції тазових органів. При затримці сечі потрібна катетеризація сечового міхура. При затримці дефекації хворим проводиться клізма.

Профілактика інфекційних захворювань

Як відомо, лежачі пацієнти належать до категорії тяжких і входять до групи ризику розвитку інфекційних захворювань. У таких хворих часто з'являються пролежні - локальні ділянки запалення і некрозу. Особливо в тому випадку, коли хворий довгий час лежить в одному положенні. Через це в місцях кісткових виступів відбувається застій крові та лімфи, що призводить до мацерації, інфікування і некрозу.

Догляд за хворими після інсульту в даній ситуації повинен включати щоденні гігієнічні обтирання (якщо можливо - використання ванни або душу) та обробку ділянок ризику утворення пролежнів розчином камфорного спирту. Постіль хворого рекомендується змінювати якомога частіше, не допускати утворення на ній складок. Після споживання їжі бажано її перетрушувати, щоб прибрати крихти. Кожні 2 години необхідно змінювати положення пацієнта в ліжку.

Іншим досить частим ускладненням у лежачих пацієнтів $\epsilon$ пневмонія. щоб запобігти їі розвитку, рекомендується уникати переохолодження хворих (а також і перегріву). Показано періодичне провітрювання кімнати, ретельне прибирання. 3 метою профілактики можна попросити у лікаря рецепт на ін'єкційні або пероральні антибіотики.

Порушення дихання у неврологічних хворих може бути зумовлене ураженням дихального центру, але часто воно пов'язане із скупченням слизу, затулянням глотки і гортані коренем язика або аспірацією вмісту шлунка при блюванні. Для запобігання порушенням дихання відсмоктують слиз із носової частини глотки електровідсмоктувачем (у домашніх умовах - за допомогою гумової груші або шприца Жане).

У хворих на геморагічний інсульт спостерігається підвищена чутливість до зовнішніх подразників (світло, шум). Тому, при можливості, таких хворих кладуть в кімнату зі зменшеним освітленням, зашторюють вікна.

Доглядаючи за неврологічними хворими, потрібно дотримуватися правил медичної етики і деонтології $[10,12]$.

\section{Відновлення мови}

Досить часто у пацієнтів, які перенесли інсульт, спостерігаються розлади мови. Вони можуть бути як незначними (легка шепелявість або проковтування 
букв), так і повністю позбавляють пацієнта мови (аж до видавання ним окремих звуків).

3 іншого боку, пацієнт може не усвідомлювати того, що йому говорять, що написано на аркуші паперу. В даному випадку має місце сенсорна афазія, впоратися з якою значно складніше, ніж з порушенням мови.

Відновлення після інсульту, який супроводжувався втратою мови, необхідно починати з розмов із пацієнтом. Якщо хворий розуміє, що йому говорять, він може самостійно намагатися відповідати або просто відтворювати ті ж самі слова. Однак коли розвинулася сенсорна афазія, пацієнта необхідно вчити всьому заново - пояснювати букви алфавіту, показувати, як вони пишуться [9].

З часом мова після інсульту почне поступово відновлюватися. Головне - не кидати зроблених спроб і наполегливо йти до кінця.

\section{Психоемоційні розлади}

На жаль, багато людей, які перенесли інсульт, належать до групи ризику з розвитку даних ускладнень. Адже будь-яке захворювання для людини - стрес, а тут відбувається практично повне вимикання людини 3 товариства. На тлі цього багато хворих, які усвідомлюють свій стан, замикаються в собі, відгороджуються від родичів, які прагнуть їм допомогти. Все це несприятливо позначається на проведеному лікуванні і призводить до затримки повного виліковування після інсульту. Не варто намагатися піднімати настрій пацієнтові ліками - $є$ ризик розвитку тяжкої постмедикаментозної депресії.

Відновлення після інсульту потрібно поєднувати з активним спілкуванням із пацієнтом. Необхідно періодично розповідати йому що-небудь веселе, допомагати розвіятися. Тільки тоді людина перестає замикатися в собі, бачачи, що ще комусь вона потрібна. Поліпшується ії настрій, з'являється інтерес до життя.

\section{Неврологічні порушення}

Багато інсультів супроводжуються порушенням чутливості уражених кінцівок. Іноді спостерігається тільки зниження больового порога; рідше можуть відзначатися анестезії (повне порушення чутливості) і парестезії (відчуття мурашок або холодку).

У такому випадку реабілітація після інсульту може виявитися марною, а з цими порушеннями доведеться миритися все життя. 3 метою підвищення чутливості рекомендується фізіотерапія - лампа «Біотрон», імпульсні струми. У деяких випадках спостерігалося відновлення чутливості (якщо вогнище ураження в головному мозку не $\epsilon$ великим).
Іноді може спостерігатися поява патологічних рефлексів (наприклад, хапальний рефлекс, який присутній у новонароджених до 4-5 місяців, не повинен з'являтися у дорослого). Якщо ж ви помітили, що у хворого рука після інсульту почала стискатися при дотику до неї, потрібно або почекати деякий час (при лікуванні рефлекс може зникнути), або звернутися за консультацією до невролога. Іноді даний рефлекс може залишатися на все життя [4].

\section{Зменшення ризику повторних інсультів}

Статистика, на жаль, така, що далеко не всім вдається уникнути повторного інсульту, особливо якщо не усунені фактори ризику. Для цього існують спеціальні дієти і ліки.

Важливим є контроль артеріального тиску. В ідеалі тиск потрібно вимірювати двічі на день - вранці та ввечері. При виникненні питань не соромтеся звертатися до лікаря. У деяких містах організовані спеціальні школи для родичів хворих, які перенесли інсульт. Їх завданням $€$ допомога в адаптації до нових умов життя як самих пацієнтів, так і осіб, які доглядають за ними.

Щоб керувати собою і протистояти стресовим ситуаціям допоможе вправа на розслаблення: потрібно зручно сісти, закрити очі та побути наодинці з собою 10-15 хвилин. Цю вправу необхідно виконувати 2-3 рази на день [13].

Щоб підсилити мозковий кровообіг і уникнути інсульту корисно робити масаж голови:

1. Стиснутими в кулак пальцями треба погладжувати голову від чола до потилиці і шиї, а потім у зворотному напрямку 2-3 рази.

2. Подушечками пальців поколочувати всю голову 1-2 хвилини.

3. Подушечками пальців поколочувати вилиці та щоки 1-2 хвилини.

4. Розтирати долонями вуха.

5. Розтирати правою рукою ліве плече.

6. Розтирати лівою рукою праве плече.

\section{Допомога при одяганні}

Найчастіше інсульт ускладнюється порушеннями рухів, іноді обмежуючи можливість користуватися однією стороною тіла. Що можна зробити для хворого? Одягати хворого потрібно в зручному для нього положенні (краще сидячи). Спочатку одягають уражену сторону. При роздяганні - навпаки, спочатку звільняють здорові кінцівки. Одяг повинен містити просту фурнітуру (перевагу потрібно віддавати липучкам замість ґудзиків, взуттю без шнурків), бути вільним і не одягатися через голову. За допомогою простих 
пристроїв можна допомогти хворому самостійно одягнутися. Наприклад, прикріпити до блискавки петлю на мотузочці.

\section{Як правильно помити хворого?}

Щоб процес миття проходив легше, потрібно подбати про те, щоб ванна кімната була підготовлена. Перевірте чи знаходяться предмети гігієни (мило, зубна паста, шампунь) в межах досяжності.

Перевірте відсутність у ванній кімнаті протягів, чи достатньо тепло в приміщенні.

Важливим є стан підлоги - вона ні в якому разі не повинна бути слизькою. Якщо є сумніви, покладіть спеціальний гумовий (або виконаний з будь-яких інших нековзних матеріалів) килимок. Аналогічний килимок варто постелити і в саму ванну. Необхідно виключити будь-які можливі перешкоди по дорозі у ванну кімнату.

Для зручності хворого рекомендується встановити поручні на стінах. При визначенні температури води користуйтеся перевіреним методом - перевірка ліктем. Починати гігієнічні процедури необхідно з обличчя і рук хворого.

Ділянку статевих органів потрібно мити в останню чергу.

Вимиту ділянку тіла необхідно ретельно перевірити на предмет залишків миючих засобів і ретельно висушити. Під час перебування у ванній кімнаті хворому краще за все сидіти на стільці, попередньо на ніжки якого потрібно прикріпити гумові наконечники, або можна поставити стілець на рушник, що допоможе уникнути ковзання [6].

Для миття голови і часткового купання краще використовувати переносний душ. Це зручніше, якщо ви миєте хворого в лежачому положенні. У будьякому разі лежаче положення у ванній $\epsilon$ найбільш безпечним.

Слідкуйте за тим, щоб кількість миючих засобів (шампунь, зубна паста) була мінімальною, особливо це стосується зубної пасти, оскільки при деяких наслідках інсульту порушується ковтання і може виникнути удушення. Що стосується гоління, то в цілях безпеки хворого краще використовувати електробритву.

\section{Пристосування в побуті}

До них належать спеціальні поручні і ручки в коридорі, ванній кімнаті, пристрої для користування однією рукою, інвалідний візок.

\section{Професійна та соціальна адаптація}

На жаль, досить часто після перенесеного інсульту в людини втрачаються професійні навички. Цей стан можна купірувати, спробувавши повторно навчити пацієнта трудової діяльності. Якщо ж ії відновити не вдається, людині встановлюють групу інвалідності (зазвичай третю). Це стосується спеціалізованих навичок (наприклад, не рекомендується повертатися до роботи лікарям - особливо нейрохірургам, токарям, ювелірам). При цьому здатність до спільної праці та самообслуговування може зберігатися.

Висновки. Існуюча на сьогодні система реабілітації хворих із таким захворюванням, як інсульт, $\epsilon$ ефективною тільки при комплексному мультидисциплінарному підході. Поряд із медичною, фізичною та соціальною адаптацією повинна постійно проводитися роз'яснювальна інформаційно-просвітня робота з пацієнтами та їхніми родичами.

Головне завдання медичної сестри - допомогти у вирішенні загальних питань, що турбують людей після інсульту та їх рідних. Сучасна медична сестра повинна володіти глибокими знаннями, які передбачають проведення постійної освітньої та просвітницької роботи у питаннях профілактики та реабілітації хворих після інсульту, психологічної підтримки їх родин, а також надання консультативної допомоги з догляду та відновлення хворих після інсульту. Особлива увага приділяється психологічним реакціям родичів на хворобу і методам відновлення їх душевної рівноваги.

Доглядаючи за хворими, які перенесли інсульт, необхідно пам'ятати, що людина, раптово втративши здатність працювати і спілкуватися у звичному для неї середовищі, вимагає до себе проявів не тільки моральної підтримки, а й ласки і доброти.

У цілому реабілітація після ішемічного інсульту відбувається швидше і легше, ніж після геморагічного. Багато хворих досить скоро повертаються до звичного способу життя, а молоді й працездатні особи навіть відновлюють навички на колишній роботі. Вихід і наслідки від перенесеного захворювання залежать від терпіння, завзятості і бажання до відновлення не тільки з боку хворого, але і з боку його рідних. Головне - вірити в благополучний результат, тоді й позитивний результат не змусить себе довго чекати.

Дотримання принципів медсестринського процесу при роботі з такими пацієнтами допоможуть медичній сестрі уникнути помилок у догляді та реабілітації всіх хворих. Проведення медсестринського процесу в реабілітації і навчанні родичів $є$ ключовим моментом у профілактиці виникнення інсульту і адаптації до нових умов життя. 


\section{ЛITEPATУРA}

1. Літвиненко В. І. Сестринська справа / В. І. Літвиненко,

Н. М. Касевич. - К. : «Медицина», 2011. - 816 с.

2. Скоромец А. А. Нервные болезни / А. А. Скоромец, А. П. Скоромец, Т. А. Скоромец. - М. : «МЕДпрессинформ», 2013. - 560 c.

3. Уніфікований клінічний протокол медичної допомоги. Гострі порушення мозкового кровообігу. Ішемічний інсульт. - К., 2012. - 76 с.

4. http://kafanest.kiev.ua/Downloads/Terapia\%20 gostrogo\%20ishemichnogo\%20insultu.pdf

5. http://www.aif.ua/health/life/1441700

6. http://supermg.com/zdorov-ja/2545-jak-dogljadati-zahvorim-pislja-insultu.html
7. http://healthdnepr.kiev.ua/ru/novini/pres-reliz_shkola_ stop-insult.html

8. http://medicine.co.ua/porad-vid-likariv/406-vidnovlenapisla-insylty.html

9. http://live4x.ru/ukraine/articles.php?id=70

10. http://bukvar.su/medicina-zdorove/122392-Uhod-zanevrologicheskimi-bolnymi.html

11. http://stylezhinki.ru/zdorov-ja/4783-dogljad-zalezhachim-hvorim-vdoma-pravila.html

12. http://coolreferat.com.ua/netw/main.html

13. http://promedical.com.ua/hvorobi/insult/

Отримано 27.10.16 